\title{
Speaking of Flowers: Theatre, Public Culture, and Homoerotic Writing in Nineteenth-Century Beijing
}

Wu Cuncun and Mark Stevenson

This paper examines the nineteenth-century flourishing of a homoerotic theatre literature paralleling the development of jingju (Beijing opera), theorizing its impact on public culture in the Chinese capital. Popular among literati gentlemen, "flower guides" (huapu) extolling the beauty of boy actors (xiao ling) have left a valuable record of the busy social life that centered upon Beijing's theatres and nearby restaurants and nightclubs. With reference to the writings of Roland Barthes the authors argue that flower guide circulation contributed to the formation of new types of public space and new ways of "performing the self" associated with theatre in early modern China, a space they call "epitheatre."

Wu Cuncun (senior lecturer in Chinese, University of New England, Australia) is the author of Homoerotic Sensibilities in Late Imperial China (Routledge, 2004). Mark Stevenson (senior lecturer in Asian studies, Victoria University, Australia) and Wu have been collaborating on the study and translation of premodern Chinese erotic and homoerotic literature for ten years. They are currently working on a study of the role of huapu literature in nineteenth-century Beijing social life as well as on a sourcebook of homoerotic writing in Chinese history.

As a minor literature composed and consumed by China's nineteenth-century literati elite, "flower guides" ( $h u a p u$, also "flower register") provide opportunity for exploring vital questions of popular culture in late imperial China, questions relating to theatre and public culture, elites and their relationship with popular literary fashion, and the interaction between official and unofficial dimensions of public life. 
$H u a p u$, in the sense addressed here, commenced in the late eighteenth century as personal records by elite men fascinated with the boy actors of the Beijing stage. Yet, while evaluation of actors remained their focus for more than a century and a half, the huapu represented much more in the aesthetic they came to contain and in the fashion of their circulation. Equally important, because they were composed by literati men, they were intimately linked to the perennial rhythm of the imperial examinations in Beijing. Their popularity also received considerable impetus from the new printeries of Shanghai. These wider connections of the huapu deserve more extended discussion than is possible here; nevertheless, we will draw on a general understanding of these wider issues in addressing another set of questions: How are the huapu to be defined? Where should they be placed in terms of Chinese literary taxonomies? Where do they fit in terms of contemporary conceptions such as popular and elite, high and low? ${ }^{1}$ What can we learn about Chinese cultural and social history-and doing cultural history-by asking these questions? And what do we learn about cultural categories that have remained unstable in the West?

In short, in this paper we examine how huapu and jingju together created new literary and social spaces. Understood as both a documentary and a literary form, huapu facilitate questions that touch on the relationship of theatre to society. Huapu existed in several realms of public culture at once: theatre, literati socialization, commercial print media, and traditions of courtesanship and prostitution. The literati elite in Beijing can probably be identified as the unifying element among them, and the genre is closely associated with literati privilege and power. In existing across several cultural spaces at once the literati composition of huapu brings to life a realm we propose to call "epitheatre" (Greek: "above or in addition to the show"). ${ }^{2}$ As a form of epitheatrical literature the huapu focus upon happenings around and about the theatre: extensions or aftereffects of performance events and spaces that are dependant on the theatre yet are not necessarily concerned with plays or playhouses (and therefore not straightforward theatre writing or criticism). In the case of huapu, an epitheatrical genre centered on jingju (usually translated as "Beijing Opera" or "Peking Opera"), the most centrally important extension of the theatre was the creation of spaces for homoerotic interplay between elite men and boy actors.

\section{What Were Huapu?}

Autumn Hibiscus was stylish, but also pretty and carefree, thus satisfying men of both high and low taste. He had a natural ability to hold his wine. He was always wholehearted in his affection, treating rich and poor alike, and whether a 
customer arrived in silk cap or cotton jacket, he would offer the same high level of courtesy.

-Xiangxi Yuyin, Fengcheng pinhua ji (Notes on

Flower Appreciation in the Phoenix City, ca. 1874;

Stevenson and Wu 2008: 46)

Huарu and the boy actors they portray remain largely invisible in the histories of late imperial China and Chinese literature. In Homoerotic Sensibilities in Late Imperial China, Wu Cuncun has provided the first overview in English of this unique literary genre (Wu 2004: 116158 ), tracing the origin of "flower guides" to discourses of connoisseurship in late imperial China (see also Clunas 1991). In the Ming dynasty (1368-1644) huapu referred to guides to flowering plants. By the late Ming the term referred to guides to famous courtesans, particularly in the Lower Yangtze region. "Flower" (hua), with its connotations of ideal feminine beauty, had long been applied to courtesans. In Qing dynasty (1644-1911) Beijing, the rise of theatre-based male same-sex prostitution from 1790 onward meant that the term huapu was reappropriated to denote small books introducing the boy actor stars (most of whom played female lead $[\mathrm{dan}]$ ) of the all-male troupes. ${ }^{3}$ The "flower guides" of the nineteenth century, then, became primarily concerned with descriptions of boy actors (predominantly thirteen to eighteen years old) and their relationships with literati men. The books' interest today is predominantly in the information they provide on the sociology of theatregoing in nineteenth-century Beijing and the world of male "flowers" and male same-sex prostitution.

Young singers and actors in traditional China, regardless of sex, had always been vulnerable to associations of sexual servitude $(\mathrm{Wu}$ 2006a). Libertine male sexual experimentation during the last century of the Ming dynasty gave rise to a homoerotic vogue among significant segments of the literati elite (Wu 2004), supported by a sensibility of male beauty that found expression in the circulation of songboys (Vitiello 1996; Volpp 2002) - a situation that continued in the Qing dynasty (Wu 2004: 29-56). In the last century and a half of the Qing dynasty this sensibility brought boy actors to the forefront of jingju, creating a star culture focusing on the "flowers" of the stage (Mackerras 1972: 44-48, 150-152; Tian 2000). Boy actors were also available to entertain aficionados and their friends offstage, serving sexual and romantic fantasies of "sublime love" (McMahon 2002).

Huари emerge at a point when theatre entertainment among the Chinese elites had already shifted from a context of private viewing into new public theatres. ${ }^{4}$ This was particularly the case in Beijing; indoor public theatres caught on more gradually in the provinces. Before the 
Qing dynasty, most contact with theatre for China's elites meant either viewing a performance on a stage located within a private garden setting, attended by family members and guests (and these could be very large gatherings on special occasions), or it meant attending performances sponsored by the imperial court (which could also be understood as a special case of the first type, with the invited audience limited to scholar-officials). Public folk performances were common, but they were treated by elite men as curiosities rather than entertainment that satisfied their own cultural needs. Furthermore, while elite men had access to popular theatrical spaces, the reverse did not hold, and the two audiences had tended to frequent different spaces.

In the Qing dynasty, as jingju stabilized, we see a new form of public space in which official and mercantile elites share the same performance events as the general (male) public. The new theatrical spaces offered a different experience than that previously enjoyed by elite men. First, performances could be enjoyed all year round as the theatres claimed a stable space within the urban landscape, and the program was constantly renewed. Where once theatre viewers were guests called to enjoy a predetermined program-held at the home of an associate-they were now consumers of mass culture who had a range of theatres and programs from which to choose. Second, men could choose from a range of daily sessions, and this allowed them to fit theatre attendance into their own work schedules. Not inconsequentially, this also allowed a certain level of addiction to the theatre. Third, the theatres became new spaces in which friends could meet regularly outside official or family contexts. While many men record visiting theatres alone, there are many more descriptions of them attending with friends, and eventually of friendships being to some extent defined by a shared experience of the theatre. Fourth, theatres had their origins in tea halls, and it was not long before they spawned sidelines such as restaurants, inns, and even institutions resembling nightclubs where men could gather together as well as mix with their favorite actors (the siyu, or "private apartments"). Finally, as already noted, this was a public space sharing a public culture that included many more types of person than an individual's own set. All of these new features of urban leisure appear to have evolved out of a single mid-eighteenth-century innovation by Beijing tea hall proprietors: the introduction of theatrical performances in competition for an increasingly cashed-up clientele.

Nineteenth-century huapu added one more important dimension to aficionado enjoyment of the theatre. Men were "reading" theatre as much as they were viewing it (women did not have access to public theatres in Beijing until the early twentieth century), and many hиари record that when men did attend the theatres their interest 
focused more on the boy actors' appearance than on the literary or musical experience. Indeed, for elite men, the "literary" experience of the theatre was postponed and transposed into the composition and enjoyment of huapu, which were written by either individual theatregoers or informal "societies" and were often the result of competitions or other forms of ranking. Some huapu were simple lists accompanied by brief appraisals; others gave detailed accounts of romances. For their authors the small books served as a means of publicizing their romantic refinement, and for the boy actors the listing could mean endorsement and a brief chance at stardom. Most were published and circulated privately, but more literary examples also found outlets in the flourishing Beijing book trade. Most that have survived were collected by local historian Zhang Cixi (Chang Tz'u-hsi, 1909-1968) in the first decades following the collapse of the Qing dynasty in 1911 (Zhang 1988). ${ }^{5}$

\section{Varities of Huapu}

Flower-guides, flower-guides,

Epitome of the capital's pleasure quarter.

So much bewitching beauty to embrace,

How the souls of those who come to the capital are stolen.

Souls stolen, souls stolen, but what vivid reading it all makes in print.

A Teasing Song Offered in Fun (Tiaoxiaoling),

by Guangzhou's Master of Listening to

Spring Hall (1874) ${ }^{6}$

As noted above, prior to the Ming dynasty the term huapu was limited to writings on flowering plants, and they therefore fell within the genre of catalogues and manuals (pulu). Late Ming guides to courtesans are similarly recognizable as biji, or miscellaneous notes. ${ }^{7}$ The huapu of nineteenth-century Beijing theatre combine two forms of writing: the documentary list and the miscellany. As the song above captures so well, they served at one level as a guide to the pleasures to be found in the capital, but often also contained irresistible hints of someone's intimate exploits or personal ruin. Master of Listening to Spring Hall's song informs us that huapu covered both functions: guide ("so much bewitching beauty to embrace") and amusement (at the expense of those who suffer from "stolen souls").

The first homoerotic huapu for which a clear date is available is the Yanlan xiaopu (A Small Book on the Orchids of Yan), which Wu Changyuan composed between 1774 and 1785, the year of its printing. ${ }^{8}$ According to Wu's own preface the initial inspiration for his book was 
an ink-wash painting of orchids on a folding fan by the actor Wang Xiangyun, which he celebrated in verse and prose. The project grew, and he had soon collected 138 poems from his circle documenting the beauty and talents of sixty-four actors. The resultant book was a fully developed work of biji literature, arranged in five chapters (juan) preceded by an author's preface, a friend's encomium, and a "users' guide" (liyan) by the author, and concluding with a friend's postscript. Wu's preface goes on to suggest that his endeavors may even have instituted the fashion for huapu composition. Repeating a common refrain in works focused on "male beauty," he also claims to be redressing a gender imbalance in the literary accounts of entertainers and beauties (or courtesans) in China's past, which were "limited to female actors of dan roles" (Zhang 1988: 5)..$^{9}$ That said, it is more likely that Wu gives his more central motivation in the closing lines to the preface in a reference to "the bustling life of the capital"; it was the special atmosphere in Beijing theatres flourishing at the southern gate to the imperial city (the Xuanwu Gate), that prompted him to set down his account of the prettiest boys of the city's acting troupes.

As he ends his preface $\mathrm{Wu}$ also predicts that the huapu genre he is claiming to have invented will flourish, evidence that he felt a new sensibility in the air: his "crude rock" is to be followed by an "avalanche of jade." Few huapu from the early nineteenth century neglect to mention A Small Book on the Orchids of Yan, and so, whether there were earlier precedents or not, Wu's book came to be the work with which other authors compared their own, inspiring a new genre of minor literature that was to undergo several developments over the next century. Nevertheless, a caveat is needed. A Small Book on the Orchids of Yan was not the first collection of verse by a group of Chinese scholars celebrating the beauty of a boy performer: poems, later collected under the title Jiuqing tuyong (Dedicatory Verses from the Portrait of Jiuqing), were inscribed by various parties on a portrait of the famous songboy Purple-Clouds (Ziyun) one hundred years earlier, in the mid seventeenth century. There is a strong likelihood that Wu Changyuan was not aware of this work's existence, given that Jiuqing tuyong was not available in published form until the 1930s, when the poems were included as part of Zhang Cixi's Qingdai Yandu liyuan shiliao. Prior to this, the verses had remained on the painted scroll (and one mid-Qing hand-calligraphed copy), ${ }^{10}$ their existence known only by a relatively small circle of art collectors.

Zhang Cixi's decision to include Jiuqing tuyong together with the huapu collected in Qingdai Yandu liyuan shiliao (Zhang 1988: 979-1001) implies a similarity the earlier work shared with the genre. Comparison of Jiuquing tuyong with A Small Book on the Orchids of Yan also alerts us 
to a number of differences that help clarify huapu as a genre. Both books were motivated by either a central friend's romantic attachment to the singer or by the admiration of a group of men for a young male actor, respectively. Both anthologies concern a single painting, the first a portrait of the singer, the later an ink sketch of orchids attributed to the boy actor himself. In each case the painting serves metonymically as a focus for dedicatory verses (or encomia) that celebrate the young man's beauty.

What is different about the earlier Jiuqing tuyong, when compared to A Small Book on the Orchids of Yan and other huapu, is an absence of references to other songboys. In contrast, even where A Small Book on the Orchids of Yan and other huapu have a single boy actor as their central focus, they always place him, however loosely, in relation to a set of contemporary actors (even if the reference group is sometimes just a single troupe). A second, less generalized difference, is that A Small Book on the Orchids of Yan and other huapu are not limited to verse, but may include verse, documentary prose, prose reverie, narrative, and lists. These two innovations within the new huapu genre reflect the major shift from sharing private, elite entertainment within gardens (where the actor being lauded was a favorite in a small troupe owned by a friend) to attending public theatre spaces (where literati men could watch and meet a large number of actors owned by different troupes). The two works also reflect a shift in geography, from the Lower Yangtze (in the south) to Beijing as a new focus for literati fashion, and in the age of the writers from established to younger men. Jiuqing tuyong clearly emerges from a tradition of small troupes of household entertainers (jiayue) owned by influential literati in the south. Huapu, on the other hand, were not necessarily composed by influential literati, the contributors most often being young, in their early twenties, and the huapu increasingly reflect the theatre life of a public street culture located in the Qing capital. One problem we will return to below, however, is how this can be understood as popular culture.

So far we have been outlining a working model of the huapu as a genre, and several features emerge. The single most important element is a focus on the description of young actors, mostly those playing dan (female lead) roles, although other roles, including sheng (male lead ${ }^{11}$ ) were also popular. Huapu, as lists or catalogues (pu), also describe more than one actor, and it was usual that the actors be ranked, or at least compared via tropes of connoisseurship. By comparing the relative merits of actors, huapu also served as a vehicle for literati "authors" to display themselves and their friends as the epitome of refinement and good taste. Within these broad parameters the huapu vary considerably: 
some are as long as five juan, include extensive preface and postscript material, and contain narratives that cover several years; others are only a few pages long, and list the "reigning flower" (huawang) of a single year or season. Within this range it is possible to identify at least four major types of huapu: simple "flower rankings" (huabang), collected mini-biographies of actors, documentation of actors' "private apartments," and narrative accounts of literati and their relationships with actors (juhua). Some of the larger huapu inevitably combine a mix of these approaches, commonly arranged in order, with mini-biographies making up the first juan, followed by flower rankings with accompanying verse eulogies, and then accounts of the literati and their actor lovers.

\section{FLOWER RANKINGS}

As the term huabang or "posted listing (or ranking) of flowers" makes clear, this form of huapu aimed at publicizing judgments on the most attractive actors of the day. This was one of the most common types of huapu along with the mini-biography (discussed below). There were two basic forms, one where a literatus developed his own assessment of the actors known to him, and another where a group of fellow aficionados documented their discussions or elections. Assessments of attractiveness (seyi, “appearance and talent”) covered attributes such as stylishness (yun), accomplishments or cultivation (duocaiduoyi), and character ( $d e$, e.g. loyalty, modesty, etc.). The topic of actors' stage performances was more or less bypassed in discussions of taste. Huapu were part of a star system that focused on individuals epitomizing particular qualities, and they were that system's most essential form of expression. Huapu could play an important role in an actor's rise within the star system, but it may not have been the actors who most benefited from the process of ranking; rather, the publication of rankings was oriented around the prestige of the literati authors who earned recognition as men of taste.

This last aspect of flower ranking, its reflection of glory on the authors of the lists, relied in part upon huapu being composed in a highly stylized language that drew upon earlier discourses of connoisseurship and literary criticism. Bohua Jushi's Yantai jiyan ershisi huapin (Twenty-four Styles of Flowers from the Assembled Beauties of Beijing, 1823, in Zhang 1988: 1037-1055), for example, alludes through its title to the Twenty-Four Modes of Verse (Ershisi shi pin) by Sikong Tu (837-908), and it was not the only huapu to draw on Sikong's classifications. This suggests that authors were not merely claiming recognition for their taste in young actors; rather, display of their own poetic virtuosity was just as important a function of huapu composition, if not more so. The 
following entry from Yantai jiyan ershisi huapin captures something of the extremes that this style could reach:

Spring Stage Troupe, Wang Xiaoqing: nicknamed Loving-Cloud, also nicknamed Cloud-Dear, from Anqing, residing at Abundant Celebration Hall.

Judgment: Displays a particularly fine ability to hint amorously with his eyes, and to understand what is in the hearts of others. That lovely moodiness might hide an underlying intelligence.

Loving glances, eyes limpid as a spring brook, Cheeks and eyes dusted in crabapple flower tones.

Soaring swallow leaving other flowers behind, ${ }^{12}$

Flitting oriole singing in the purest notes.

Headscarf infused with his fragrance,

Sleeve lifting like the soft spring breeze.

Too fragile to risk strong passions,

A glance as distant as autumn waters are broad. (Zhang 1988: 1045)

A more straightforward approach is found in the anonymously authored Qingtian waishi (Unofficial History of Passionate Skies, 1895, in Zhang 1988: 683-697). This author's approach is less ornate, limited mostly to prose, and focused on "objective" details, and in his preface he playfully places emphasis on a strict series of procedures that reflects in part the processes of the civil examination system. This is a late huapu somewhat untypical in the attention it gives to operatic performance. In this respect it also includes actors of all roles, and may not have been as directly associated with homoerotic fashion, although its author does not omit to mention the actors' "private residences." The following is an entry for the actor known as Orchid Fragrance:

\section{Flair Category}

[Private residence] Gorgeous Spring Hall: Orchid Fragrance, surname Wang. Fifteen years old, from Beijing. Plays upright beauty roles. Also good on the fiddle.

Belongs to the Celestial Fairy Troupe. Known for his roles in Third Mistress Disciplines the Son (Sanniang jiaozi), Qiu Hu Mistakenly Flirts with His Own Wife (Qiuhu xiqi), Match Made under a Decorated Archway (Cailou pei), Departure Sworn by Three Claps (San jizhang), Chasing His Wife up the Hill (Paopo), Descending into the Garden (Luoyuan), The Cosmic Sword (Yuzhoufeng), The Battle for Pu Pass (Zhan Puguan). Particularly outstanding in his role alongside Water-Chestnut Fragrance in Calling on the 
Cold Cave (Tan han yao), where his performance rings like a bel canto solo at midnight. I could not stop myself from gasping "I'm dying!" over and over again.

Flair at once beautiful and chill, drawing on the depths of passion, When categorized among the flowers, glossy privet comes to mind. For all the world an orchid, so pleasing do all find him, His fragrance condensing in dewdrops, song-voice gentle and calm. (Zhang 1988: 686-687)

The poem with which this and the other entries close is partly a word game based on the name of the category (Flair Category) and the name of the actor selected to represent it (Orchid Fragrance), the four characters heading each respective line. This and similar forms of literary play became a regular feature of huapu as the form developed.

\section{Mini-Biographies}

The authors of huapu liked to think of themselves as protectors of the actors of whom they were most fond. Consistent with this romantic sentiment they often state how they wish to preserve, in the flower guides, something of the person of those actors to whom they had become attached. There can be overlapping of this category with the previous one, although here there tends to be less interest in ranking the actors and more in an overall assessment of the person. The tragic tone that enters some of these narratives again feeds the gratification literati gentlemen imagined they gained by being the boys' protectors.

The content of the biographies, while slightly more comprehensive, is not very different from what we find in most of the flower rankings: date of birth, ancestral district (jiguan), troupes, trainers (shifu), particular abilities and best plays, appearance and character, life milestones, hobbies, and talents. Life milestones are not always mentioned, again a measure of the tension authors experienced between identifying as rescuers or consumers. The following example comes from Guide to the Jade Shoots of the Dingyou Year (Dingnian yusun zhi, 1837, in Zhang 1988: 327-343). This is not the full entry, but we quote it at length to show how enraptured description predominates over biographical detail. The passage also illustrates the feminization of actors in huapu and the elegant interior of the actors' "private apartments" (the subject of the next huapu category):

Majestic Delight: courtesy name Rain Fragrance. His teacher was Tan Tianlu, manager of the Spring Stage Troupe. Tianlu was very famous [as an actor] in his youth. For some reason he received a jail sentence. After returning to Beijing he began to re-establish his old career, 
and once he had found Majestic Delight he felt he then had what he needed. [Majestic Delight] had figure and looks that were pure and stylish, the impact being not unlike the rich scent of jasmine blossom. Each summer evening [at his residence] the bamboo screen was rolled down and green gauze curtains were hung everywhere. The sky beyond the willow was clear, a full moon rising in the night. Following his bath he cooled himself with a palm-leaf fan. He wore a long gown of light foreign weave which was covered in moon shadows reflected from the garden's flowers. Once refreshed-flower shadows surrounding the winding corridor-he set up a bench of stained bamboo covered in matting woven from red gloryvine. He would take out his cosmetics box and mirror, ready to start applying his makeup for the evening. In a light green porcelain box he kept stamens from jasmine flower, from which he knotted two large butterflies to fix carefully in front of each ear, offset by a shower of fragrant orchids. His raven locks made his face appear as white as jade, with gold specks through his hair. A moment later he began to emit a bewitching perfume, his body an orchid from tip-to-toe. If you were able to join Rain Fragrance you would enjoy this same overwhelming experience. ... (Majestic Delight is employed by the Spring Stage Troupe, and resides at National Fragrance Hall, in Zhujia Lane. . . .). (Zhang 1988: 340)

There are more than twenty huapu available that approach the subject of actors through collections of short accounts similar to this one. One of the first things a reader will notice is that the "biographies" are more of an encapsulation of what the literatus finds most captivating in the actors known by his circle, and that they add very little to the usual background details of an actor's life. Revealing little about the realities of the actors' lives, they prefer to tell us more about how the men who visited the actors preferred to imagine them. We could also expect that something of those imaginings became part of the aspirations of the actors themselves.

In the above example, the presentation of general background information quickly becomes interwoven with, or gives way to, an impressionistic account of a visit to the home of the actor Majestic Delight (Hongxi). The account first surrounds the actor with his lavish apartment, another world where the play of light is dreamlike. After establishing the general atmosphere, attention turns to the young man's toilet and associated paraphernalia that signify good taste and knowledge of luxury items. Finally, as he makes up his hair, the passage paints the bewitching effect of his figure, described in the most feminine terms the author was able to pen.

Parenthetically the passage concludes with his "contact details"as well as listing other actors from his troupe that were also available 
there (not included in our extract). The "private apartments" of the actors are the focus of the next subgenre of huapu.

\section{Accounts of Private Apartments}

A number of huapu were organized, either entirely or in the main, along the lines of a master tutor's "private apartments" (siyu). Private apartments were an institution very much based on the two forms of livelihood most directly associated with young actors in Beijing: acting and prostitution. They consisted of large houses owned by the master tutors (shifu). While the hiring out of actors to perform with opera troupes was purely a business transaction, the hiring out of actor-prostitutes (xianggong, lit. "gentlemen") had to be couched in a manner that was (or allowed it to be imagined to be) absolutely free of the taint of business. ${ }^{13}$ While it occasionally reads as if a literatus is visiting the private apartment of a particular actor, the apartment was in fact owned by the tutor and served for all purposes as a high-class brothel. The private apartments were both the residences where the actors trained and the rooms where they met with Beijing's scholar-official elite.

From the point of view of their paying visitors private apartments must have been something like an exclusive nightclub: they were luxuriously appointed and provided for their every comfort (some came to describe them as a "home away from home"). However, as well as providing descriptions of luxury and elite taste during the nineteenth century, the reporting of private apartments in the huapu also furnishes us with important practical data, such as the stage names and number of young men that made up the school of a particular tutor, the troupes with which they were associated, their ages, and often their backgrounds before entering the acting profession, as well as their training lineage (liupai) and the dramatic roles they played best. This form of huapu includes much information that allows for the piecing together of a more comprehensive picture of actors and their dealings. Only three or four huapu of this type have caught our attention to date. In this sense they are hardly representative of the genre, but it is highly likely that these will become some of the most important documents for the historical reconstruction of the "private apartment system," including the relationship of siyu to troupes and theatres, as well as their role in the lives of actors. They promise to provide such information as the number of siyu in Beijing and their locations, the types and numbers of actors in each siyu, the backgrounds of their masters, and the relationships existing between sets of actors, troupes, and siyu. In modern terms they provide "quantitative data," complementing the rich "qualitative data" of other forms of huapu. 


\section{Theatre Talk}

If the private apartment huapu are the most matter-of-fact of the subgenres, then the "theatre chitchat" or "theatre talk" (juhua), by contrast, is the most effervescent form. ${ }^{14}$ In style it is the most varied, often including a mix of elements already described in the other subgenres and combining forms across documentary prose, literary and autobiographical prose, and several styles of verse. Yet what most sets the juhua apart is the emphasis on the literati's experience of, and interaction with, the world of the boy actors ("theatre gossip" might be an apt alternative translation). In theatre talk one finds the most vivid reconstructions of the relationships elite men pursued with boy actors. While this subgenre clearly places an emphasis on self-display, wit, and entertainment, because of its subject matter it should also be read as autobiographical or biographical, and because of this the works are useful historical documents and the richest source for understanding literati motivations in their involvement in the theatre world (the subject of motivation is treated more fully in the next section).

The most representative examples of the theatre talk subgenre, listed in chronological order, are Record of the Golden Stage's Unwept Tears (Jintai canleiji), A Record of the Years 1841-44 (Xinren guijia lu), Fragmentary Records from Dreams of Past Glory (Menghua suobu), Notes on Flower Appreciation in the Phoenix City (Fengcheng pinhua ji), Leisured Conversations with Hat Removed (Cemao yutan), A Miscellany from South of Xuanwu Gate (Xuannan zazu), and Theatre Talk from Yueman Studio (Yuemantang juhua $).{ }^{15}$

Perhaps the work that most epitomizes this autobiographical trend is Xiangxi Yuyin's Notes on Flower Appreciation in the Phoenix City (ca. 1876) (translated in full in Stevenson and Wu 2008). Phoenix City is remarkable among huapu in that it preserves, in fully narrativized form, the history of its pseudonymous author's search for "true love" among the actors inhabiting the district south of the imperial capital's Xuanwu Gate, climaxing with an abortive affair with the dan Marvelous-Coral. While highly narrativized, Phoenix City at the same time manages to incorporate elements already noticed in other forms of huapu, including flower-rankings, biographical details of boy actors, dedicatory verses, and romantic lyrics. This composite form is found in late $h u a p u$, and it is evidence of a new interest in the literary potential of the genre. There is much crossover between the subgenres, and it will be evident that the following passage contains most of the themes already discussed, including the protective sorrow huapu authors exhibit over the fate of their "flowers" (we have retained, in brackets, the interlinear commentary by this stage fashionable and also integral to the pub- 
lished work). "Culivator of Orchids" is a friend of the author, and it is likely the pseudonym of this man was coined to reflect his passion for dating actors:

Cultivator of Orchids (Yilansheng) had become convinced of the need for a ranked listing of flowers. [Cultivator of Orchids is such a busybody. ${ }^{16}$ I was not in agreement, but he and Traveller Drifting in Moonlight went ahead and ranked them one by one. When it was complete, Autumn's Image topped the ranking, South Sea Fairy came in at number two, followed by Pretty Cloud, Marvellous Coral and Plum Blossom. Because they had insisted my name be added to the list of assessors, I was also dragged out of the inner-city. During the party Autumn's Image and the others were called and shown the ranked list. Each of the assembled beauties bent a knee and expressed their gratitude-only Marvellous Coral said nothing, appearing a little dejected. I wondered if it might have been because he had been unfairly ranked in fourth place, and went to console him. Marvellous Coral winced, "Why would it make me feel either honored or ashamed? My heart just goes out to those of us who have fallen into a life of ill-repute, destined as we are for misfortune-even when our fame and prices shoot high we are still nothing more than players in the opera. Why give a fig about high or low rankings?" [One so noble-minded will not follow a life of ill-repute for long.] I found his words deeply moving and quietly admired his sense of nobility. As the party ended we were still depressed. (Zhang 1988: 573; Stevenson and Wu 2008: 53)

One feature almost immediately noticeable in Phoenix City is its relatively open treatment of the question of money, something most other huapu conspicuously avoid. While the problem of money (and opium addiction) impinged on the actors' relationships with literati admirers, as a self-penned history of his relationships with several young actors over a period of around three years, Phoenix City also reveals other themes central to the author's life. He is haunted by the illusiveness of examination success, he himself is pressed for money and this means he is also haunted by his family's expectations, and, finally, while he would probably deny it-were he here to do so-he worries about his standing in front of his circle of friends. Pressure from dan to buy them out of the trade finally exacerbates these concerns to the extent that he has to break away entirely. We might therefore wonder why he would have wanted to jot down these events for others to read? A term that is used with considerable frequency in Phoenix City may offer at least a hint at an answer to this question: yunshi. While the direct translation of yunshi is "matters of refinement," and while this term's use in reference to poetry gatherings and such like had been common, in the Qing dynasty it increasingly came to refer to romantic encounters. In 
this last usage it retained purely positive connotations, and may be variously translated as "refined pursuits," "romantic anecdotes," "romantic adventures," "diversions," and "beautiful moments." As is said of one of his friends appearing in Phoenix City, the same can be said of Xiangxi Yuyin: he aimed to achieve only the "highest state of sophistication (yun)." Huapu were a means of extending the personal and shared pleasures - the romantic adventures-found and performed in and around Beijing's theatre quarter. While huapu are ostensibly focused on the flowers of the stage, in reading them literati men most of all wanted to find a reflection of themselves.

\section{Motivation and Huapu: Form as Forum}

In contrast to kunqu, for much of its history few literati took jingju performance seriously: most performances were written by the actors themselves (who were constantly revising the libretto) and much of the writing in the earlier plays was rough-and-ready. The plays and their plots were largely concerned with themes favored by the masses, such as popular and family morality (loyalty, filial piety, feminine modesty, etc.) or historical drama (particularly tales of battles and betrayal). All the same, literati gentlemen went to the theatre regularly, and they partly shared the space of theatre halls with crowds of common enthusiasts.

There were, of course, differences between the common enthusiasts and the gentlemen. The common man spent virtually nothing on his ticket, and sat (or stood) in the stalls jammed shoulder to shoulder. Literati gentlemen sat upstairs at tables for placing tea and plates of tidbits, competing for spots that gave the best view of the actors exiting the stage (in order to be able to make or honor appointments with them). From contemporary accounts, the gentlemen did not spend much time watching the shows; they arrived late and left early. Instead the theatre was a place to observe and to be observed, preferably while scoring an appointment with one of the actors and moving on to a restaurant and/or the private apartment of the actor. To be successful in this form of public ostentation it was not even required that a literatus have extensive familiarity with opera performance, it was enough that he have sufficient money-and, more importantly, sufficient sense of style-to bring off his own "performance."

There is no doubt that "performance of self" had an important role to play in theatre attendance and connoisseurship. ${ }^{17}$ But this in turn raises a number of questions: In what ways were the "performances" of men who visited boy actors judged or appreciated? And in what ways can huapu be observed to reflect those processes of judgment, or even affect or shape them? Do huapu provide a useful guide to the values and motivations surrounding literati theatre attendance? 
And can our knowledge of the theatre world help answer questions relating to the motivations shaping the huapu genre? Were huapu used, in the end, to judge the young actors who featured in them, or were they more a form or forum for literary communication or exchange between circles of elite men? And to what extent were these forms of writing still being influenced by traditions inherited from poetry dedicated to courtesans?

In the current context it is possible only to provide a number of suggestions by way of answer to these questions, and perhaps the last two questions are already at least partly answered in other studies. The importance of actors in literary and literati circulations in the decades spanning the end of the Ming and foundation of the Qing dynasty has already been noted and analyzed by Sophie Volpp in an article on the poetry that emerged around the relationship between the great early-Qing poet Chen Weisong (1662-1682) and the actorsinger Purple-Clouds (1644-1675) (for an alternative analysis of their relationship and the poetry that surrounded it, see Wu 2004: 67-80). It is clear from Volpp's analysis that in the Ming dynasty men used representations of spectatorship (or viewing) in literary contexts in which they themselves sought to be viewed or seen-not so much to be identified individually (Volpp 2002: 976-77), but as participants in a game (p. 974) partly shaped by a seventeenth-century cult of qing, or feeling (p. 975). While the poetry itself is focused on homoerotic portrayals of beautiful young actors, the motivations of the contributors are oriented more to a mutual acknowledgement achieved through homosociality, or "empathic resonance" (p. 952). In short, in the last decades of the Ming and the early decades of the Qing, elite men exchanged deeply emotional poetry as a means of cementing homosocial bonding within a particularly elevated segment of Chinese society. The primary literary vehicles for their exchanges were either courtesans or songboys. Through the Qing period songboys and actors increasingly displace courtesans in literati writing (Wu 2004).

Interestingly, as noted above, Zhang Cixi judged a certain continuity to exist between early Qing poetry dedicated to songboys and late Qing writing associated with actors of Beijing (including both within the same collection). In accepting a continuous development between literati interest in songboys and actors, we have to note important shifts. First, the early Qing writers usually portrayed songboys as outstanding individuals, and they were not in the habit of ranking the young men in beauty contests as in the late Qing. Second, the songboys were usually the property of the early Qing officials or merchants themselves (and were regularly exchanged between them), and they were usually made visible in the private space of the garden party; in the late Qing actors 
were owned by their master-trainer, and were made visible in public theatres available to men of almost any social level. Elite men participating in the late Qing love of boy actors were then required to move from one shared public space to another, from theatre to restaurant to private apartment and around again. By the end of the nineteenth century it would have been hard to tell if it was actors who were circulated among elite men or elite men who were circulating among actors, and in a limited fashion the huapu genre enabled men to record their participation and performance within gatherings at public venues, literally becoming textualized "men about town."

The question of who benefits and whose fame is at stake is consistently raised in the encomia attached to huapu:

Having reverently read your magnum opus, Notes on Flower Appreciation in the Phoenix City, I was completely swept away. If, by chance, you do not consider it too precious to allow into the open, then asking the Shenbaoguan of Shanghai to publish and distribute it would be most ideal. Preserving the names of the flowers is an act that would attract great merit, and has nothing to do with earning any reputation for yourself. (Zhang 1988: 526)

This passage from a letter by "Commandant of Flower Protection," preserved in Yilansheng's Xuannan zazu, tiptoes so carefully around the question of the author's ambitions that it is almost tripping. The ritual of attributing (or claiming) modesty was standard practice in literati writing of any kind, and had become so baroque that it included rituals concerned with not seeming too modest lest one seemed immodest in one's modesty. It reached the greatest heights in communication between friends and it appears with regularity in the huapu in which the actors become a convenient rhetorical foil, with authors shifting questions of reputation and benefit to the performers.

The excessive protests of modesty that accompany discussions of huapu authorship can be explained by the fact that we are observing a ritual that is being refined through repeated performances between close friends. However, the evasiveness itself is a sign of acute interest in recognition. Because composition was a pastime requiring considerable literary dexterity, for men investing in the achievement of the literati ideal the writing of huapu was not merely participating in a fashion, it also represented a level of refinement that purchased significant cultural capital. Repeatedly authors portray themselves as receiving more affection or respect from the actors compared to that received by their fellow aficionados.

Why would men who had entered (or were entering) the higher 
ranks of Chinese society need to have their moral and social credentials confirmed by actors whose own profession was of the lowest in social status? The answer relates to differences between ritual and social status and the emergence in the nineteenth century of new forms of status outside the rigidities of Confucian tradition. Changes in public culture and public communications allowed new admixtures of ascribed status and achieved status. These may have affected literatus and actor in different ways. ${ }^{18}$

In her Wan-Qing xiqu de biange (The Transformation of LateQing Theatre), Yao Shuyi analyses the relationship between literati patrons and opera actors (Yao 2006: 338-343), suggesting that initially the actors were haughty in their relationships with literati until the soaring popularity of the opera forced them to pander to those who could promote them through huapu. In short, she sees huapu as a form of advertising, and even suggests that for some struggling literati writing them could contribute to making a living in a budding "new occupation." There is no doubt that the huapu contributed to the fame and standing of an actor, and could even improve their earnings; however, we have not come across any evidence to suggest that literati were motivated by a book's or pamphlet's earnings. On the contrary, publishing a small book might bring fame and respect, but the absence of copyright meant that little was usually earned from publishers in direct monetary terms, and there is no evidence that actors offered writers (or that writers sought) "advertising fees" (which does not exclude more subtle negotiations). The main advantage that would accrue to a writer-outside whatever favors flowed from the pleasure an actor felt at receiving a good write-up-would be the prestige earned in his own circle.

Many of the features we have been noting suggest a reading of huapu that takes into account Roland Barthes's analysis of the function of sport in public culture. ${ }^{19}$ "Why?" asks Barthes, "Why love Sport? First, it must be remembered that everything that happens to the player also happens to the spectator. But whereas in the theatre the spectator is only a voyeur, in sport he is a participant, an actor" (Barthes 2007: 59, our emphasis). In writing and reading huapu literati men became participants (or at least putative participants) in the world of the theatre. ${ }^{20}$ They were theatregoers, but they also moved beyond being Barthes's simple "voyeurs." 21

Barthes continues, "In sport, man does not confront man directly. There enters between them an intermediary, a stake, a machine, a puck, or a ball" (Barthes 2007: 59). Barthes is speaking of men competing on the field, but in the huapu we might see two competitions (in a single game?): the competition played out exclusively between literati men (in taste and romantic adventure, in yunshi), and the competition played 
out exclusively between actors (in popularity and fame) ${ }^{22}$ Within the literati competition it is possible to see how the actors become that "intermediary, a stake" through which elite men regulate their social and cultural competition. Direct competition is still further deflected through the highly refined language of their compositions, as well as through the refined arts of modesty and self-deprecation.

"And this thing [the intermediary] is the very symbol of things, it is in order to posses it, to master it, that one is strong, adroit, courageous" (Barthes 2007: 59). Despite its ostensible triviality, for the writers and readers of huapu there was something deeply significant, personally, in the events that took shape around actors. A great deal of themselves was invested in those events: possession of an actor's affections and mastery of "flower appreciation" (pinhua) were opportunities to demonstrate worth and standing among other men. Sport's "strong, adroit, courageous" apply more, in Kam Louie's analysis, to the martial $w u$ ideal of the wen-wu (civil/martial) dyad operating in constructions of Chinese masculinity (Louie 2002), and these were not the values most literati men in the nineteenth century most ardently strove to attain, but they could easily be replaced with others: being considerate (wenrou), erudite (boxue), debonair (fengliu), and other qualities pertaining to the civil or cultivated wen ideal. It was never mere coincidence that huapu constituted a system of knowledge production, combining the two literati distinctions of literary and cultural expertise.

"What is sport?" asks Barthes. "Sport answers this question by another question: who is best?" (2007: 63). In the game(s) described by huapu it is only in the competition between actors that a winner (bangshou, zhuangyuan, or shenpin) is ever identified. The literati are, in this sense, somewhat akin to "voyeurs," but it could also be said that their game is played differently: winning an actor's favor, for example. Barthes also notes that in sport man's excellence is only sought "in relation to things. ... Occasionally one would like to make sport say something else. But sport is not made for that" (2007: 63). Which would suggest that the actors' competition cannot be compared to sport, for, as the intermediary in the game played out between literati, they have themselves no intermediary, no "thing" for which they play. Theirs is the real competition of life.

Can we really say that literati men who engaged in "flower appreciation" were playing sport? As he concludes his essay Barthes asks, "What then is it that men put into sport? Themselves, their human universe. Sport is made in order to speak the human contract" (2007: 65). Concerning huapu, we have been asking the question, "Why would men who had entered, or were attempting to enter, the higher ranks of Chinese society need to have their moral and social credentials con- 
firmed by actors whose own profession ranked them among the lowest in social status?" As strange as it might seem, Barthes's commentary (2007) for a 1961 Canadian documentary film called Le Sport et les hommes has provided us with some answers as to why (and how). Nevertheless, among the literati there are no winners, only pickers of winners. And in this their activity moves distinctly to the edge of the realm of sport-nevertheless they were more than simply gamblers.

In Barthes's model of sport there seem to be two key elements: a winner (or a winning side), and an intermediary that serves as the focus of competition (a ball, etc.). Neither of these are what the game is "about": "Speaking the human contract." In neither of the two competitions (literati or actor) described in the huapu do we find both elements coextensive. All the same, they are there, and this allows us to think heuristically about how the huapu game existed in an as yet unnamed space located between theatre, connoisseurship, and sport. In giving us access to that space huapu may allow us to think differently about how, in the nineteenth century, Chinese public culture and public spaces remained different to their European counterparts, questions that continue to dog historical analysis of Chinese social life. Despite their origins, huapu do not fit comfortably within models of connoisseurship or theatre criticism, having as they do a closer bearing on events as they unfold in the lives of the literati "connoisseurs." It is for this last reason that huapu were increasingly narrativized as the lives of aficionado became interwoven with their objects of admiration, spawning a unique cultural form that constituted a public interweaving of theatre and life.

\section{Pinhua baojian (A Precious Mirror for Grading Flowers) and the Fictionalization of $\mathrm{Huapu}$}

With the increasing narrativization of huapu it was perhaps inevitable that the genre would inspire fully fictionalized accounts, and, almost as if history had compelled it, the novel Pinhua baojian appeared in the very middle of the nineteenth century. According to the author's preface, the book, written intermittently over ten years, was completed in 1847. The earliest edition dates from 1849 (the twenty-ninth year of the Daoguang reign), and various publishing houses were reprinting it continually up until 1931. Chen Sen's own account of how the novel came to be written is classically related to the question of examination success:

Once when sojourning in the capital I served as a tutor in the household of an official from the Bureau of Review who was from my own district. While there I wrote a libretto (chuanqi) called The Plum Flower Dream (Meihua meng). While I was quite proficient at poetic allusions, 
my mastery of prosody was still poor, and so I had never shown it to anyone. The official was impressed by my ability to deploy flourishes while conveying the tenor, conveying elegance even while engaging the reader with humour. He thought I should try my hand at writing a novel (shuobu) in which I could freely express what I wanted to say, letting my brush follow my thoughts, and suggested this would be far better than following prosody and models dictated by others. At the time what I loved to work on most was serious prose and verse (guwen shifu gexing), and I felt fiction was too demeaning. Then, when I failed the examination, my situation became even more destitute, and my heart was weighed down with disappointment. It was as if everything was stored up and raging in my chest and could not get out. I spent my time at the theatres every day, trying to forget everything, and after three months I lost all resistance. I began to understand what was marvelous in their voices, their appearance and their performing skills, at the same time gaining insight into whether an actor was chaste or wanton, well spoken or vulgar, and the overall genuineness of their emotions. Occasionally, the Bureau of Review official and I would evaluate the theatre as well as swap judgments on everyone, and he said to me, "When I advised you to write fiction this is just what I meant, why not use them as the subject of a novel? If you did write such a book it would tell things that no one has previously told." Deep down I had much the same idea in mind, and so I began to conceive it. (Chen 1990: 1)

As we have repeatedly noted through this paper, most huapu were written largely on the basis of what their authors had already discussed with friends. That process of discussion is revealed in this passage from Chen Sen's preface, but, as he describes it, his friend from the Bureau of Review had the bright idea of him taking things one step further, developing their considerations into imaginative literature that had a life of its own. His description of the book's genesis also describes the work's central themes, for indeed much of Pinhua baojian is concerned with how "an actor was chaste or wanton, well spoken or vulgar, and the overall genuineness of their emotions."

Chen Sen's friend's idea for a new novel was that it should do just what they themselves had been doing, "Evaluate the theatre as well as swap judgments on everyone" (pinti liyuan, cihuang renwu). It is possible to interpret this antithetical construction as (guardedly) indicating the two groups of people, actors (liyuan, i.e. theatre, "pear gardens") and literati theatregoers (renwu, everyone, i.e., "personalities"), with which the novel was eventually concerned. We suggest this because one of the most important ways in which the novel diverges from huapu is in its willingness to grade and select winners among the literati theatregoers. As we have pointed out above, it was this step that was not possible in huapu production because of the way in which the lives of literati 
men were closely implicated within the huapu accounts. Perhaps this is also what was meant by "telling things that no one has previously told," a telling made possible only by fiction's trick of allowing a separation from historical events.

While Pinhua baoijian could in some ways be counted as a remarkable achievement of literary sophistication, it is repetitive in its parade of "flower appreciation" episodes and is for the most part driven by a single pair of ideas, that interest and disinterest in money and lust separated two kinds of person, the base and the sublime. Both actors and literati men are measured over and over against these paired criteria of money and lust. Ugliness, lustiness, venality, and poverty threaten the natural order, reflecting the logic of the scholar-beauty (caizi jiaren) literature still immensely popular at this time, where the good must find the beautiful and the beautiful the good.

\section{Conclusion}

In our reading of the range of homoerotic nineteenth century huapu, from their earliest appearance to their fullest literary development, from the simplest list to their narrative and literary extension, we have revealed a number of important social taboos, rules about money and taste and passion and lust, and also rules about the representation of social competition. Crucially, none of these were concerned with fears of same-sex desire or of stigma through connection to the world of Beijing's homoerotic nightlife. ${ }^{23}$ Pseudonyms were not used in this instance to hide anything much about either the writers or those they portrayed, but have to do with conventions relating to self-portrayal in general, and the problem of unserious writing in particular. Clearly, however, the literati at this time defined themselves as a group who should enjoy writing for pure leisure, at the same time continuing to reveal their sensitivity to the requirements of duty.

Indeed, as a form of social document, huapu illuminate literati leisure in nineteenth-century Beijing. A series of changes that took place across the eighteenth and nineteenth centuries made the theatre and its extracurricular nightlife essential for the self-distinction of the literati, but simply attending the theatre and nightclubs (siyu) was not enough, particularly as pihuang, bangzi, and yiyangqiang opera styles began to supersede kunqu and combine into a popular theatrical form Beijing could call its own. The popular roots (in terms of language, musical style, and prosody) of what was to become jingju confronted literati men with a certain ambivalence. Reflecting their physical segregation in the best seats, the huapu literature of the nineteenth century divided the theatre experience even further as it produced a parallel world accessible only to those who considered themselves paragons of 
refinement. In so doing they both turned to and created what we have called the realm of the epitheatrical: a largely literary realm where theatre always remained an important reference point, but which had a life of its own, and, in this case, that extratheatrical life included homoerotic play.

We began this article by signaling the need to define huapu in terms of Chinese categories of literature. Our analysis thus far brings us to the edge of an "epitheatrical explosion," challenging our inherited intellectual boundaries. By coining a space called "epitheatre" we have identified a need to trace theatre's aftereffects. As part of cultural life-elite or popular-theatre has always had aftereffects and influences that spread via myriad channels of communication: in coining the term "epitheatrical" we mean something more closely allied to the theatre than theatre's more general cultural effects, perhaps something analogous to the way in which "rock-and-roll" always means much more than what occurs on stage or in recording studios (and not just sex and drugs). As epitheatrical texts huapu both report on events emanating from the theatres and participate in the dramas of life. ${ }^{24}$ We have argued that the way they participate in the lives of literati men creates a form of social competition that shares something of both sport and connoisseurship, and that has its own unique space within the history of leisure. The problem is one that involves high levels of intertextual and interstitial play, and in huapu we are not always sure if we are reading theatre as performance, literature, or social effect. The social histories of leisure, popular culture, public media, and sexuality all converged in the production and circulation of the flower guides, clearly a rich genre deserving further exploration and theorization.

\section{NOTES}

1. Given that sixteenth-century Chinese writers were already making these kinds of distinctions we are reluctant to style these as "Western," but they have come to have meanings that are historically specific to our own period and mass culture following their theorization by Adorno and Gramsci.

2. The term epitheatre (epitheatron) existed in Greece to describe the outer rim of the auditorium of the Theatre of Apollo. This section was defined by the peripatos (perimeter walk) that circled the Acropolis as it crossed the auditorium, separating the upper level or epitheatron. Epitheatre, as we are suggesting it might be used, is different to paratheatre and metatheatre, although not entirely unrelated to such innovations in performance practice. In an essay on theatrical imagery in Plutarch (46-120), George W. M. Harrison (Concordia University) has used "epitheatre" in a slightly different sense to refer to "a habit of mind by which prose writers reflexively organised their works accord- 
ing to the canons of the stage" (2004: 56). In correspondence Professor Harrison has encouraged our wider use of the term.

3. Mixed-gender troupes were prohibited by imperial statute. The question of women on stage was regularly revisited in Chinese history. In the Qing dynasty women were prohibited from performing theatre initially in the tenth year of the reign of the Kangxi emperor (1671) and again in the fortyeighth year (1709). The prohibition was also recorded in the Qing legal code as set out in the Qinding libu chufen zeli (Imperially Endorsed Regulations of the Board of Civil Office), first issued in 1769 (see Wang Liqi 1981: 20, 23, 27).

4. Wu Cuncun draws attention to the mixing of status groups around new forms of public entertainment in Homoerotic Sensibilities in Late Imperial China (2004: 116), and the same observation has been developed recently by Andrea Goldman (2008: 7). These shifts are not dissimilar from those experienced in Germany around the same period; see Gadamer (1986) on social and cultural developments around the "permanent" theatre.

5. Zhang's anthology of huapu, Qingdai Yandu liyuan shiliao (Historical Materials on Opera Circles of the Capital in the Qing Dynasty) was published in 1934, followed by a supplement (xubian) in 1937. An edition with modern punctuation was published in 1988, and our page references refer to that more widely available edition.

6. This brief lyric was composed by Guangzhou's Master of Listening to Spring Hall as a contribution to a series of dedicatory verses that open Yilansheng's Pinghua xinpu (New Catalogue of Flower Appreciation) (Zhang 1988: 459).

7. Within the the Siku quanshu zongmu (General Catalogue of the Complete Collection of the Four Treasuries) classification system biji miscellanies were associated with either the zajia (miscellaneous authors) or xiaoshuo (here essays or miscellaneous works) genres.

8. A scholar based in Hangzhou, Wu Changyuan (fl. late eighteenth century) spent more than ten years in Beijing as a writer, supporting himself by collating or proofreading books for scholar-officials. Wu himself was never able to win an official position, although he was widely respected as a man of considerable learning. He is also recorded as having an interest in the folk life of commoners in Beijing, and in addition to Yanlan xiaopu his only surviving work is Chenyuan shilue (An Abridged Account of the Capital City), a digest of a massive collection of historical materials on the capital.

9. Works from the late Ming and early Qing did in fact contain many homoerotic references to songboys and actors, but in Wu's time none had yet been published as anthologies, and so his assessment may be justified.

10. The present location of the original painting, Yunlang chuyu tu (Purple-Clouds after his Bath), is unknown to us. The dedicatory verses were copied onto a separate scroll by the noted calligrapher and seal engraver Chen Hongshou (1768-1822) in 1810 at the request of a collector. Earlier, in 1731, the original scroll was recovered from an antique shop in Beijing; a later admirer, an imperial reader (shidu), had the portrait of the songboy copied 
(without the verses) by the painter Luo Pin (1733-1799) in 1795 (Zhang 1988: 998-1000).

11. When huapu refer to sheng roles they are predominantly interested in younger xiaosheng (or zhengsheng) roles. While not as popular as dan or sheng, actors playing lao sheng (senior male lead) roles could also be the focus of attention in huapu (see Wu 2006b: 80-81).

12. The actor is already a "flower" by virtue of his profession, but this "flower" soars above others like a swallow.

13. It is important to note that one and the same actor could be known as a xianggong or as a lingren (actor), depending on which of his "identities" one wanted to emphasize. While there were actors who were not usually associated with prostitution (such as those playing laosheng or hualian roles), no particular stigma appears to have been attached to fulfilling only on- or off-stage identities, or combining both.

14. It is important to note here that in the nineteenth century most juhua miscellanies were flower guides (huapu), and it is only with the decline in homoerotic fashion in the early twentieth century that the subject matter shifts away from the appreciation of boy actors and broadens into general theatre and celebrity anecdotes and appreciation, the form they continue to take today.

15. The last of these, Li Ciming's Theatre Talk from Yueman Studio, was in fact assembled by Zhang Cixi from extracts of Li's Diary of Yueman Studio (Yuemangtang riji), a work covering a period of forty-one years.

16. Note that it was in all likelihood "Cultivator of Orchids" (Yilansheng) himself who inserted this observation.

17. Themes of self-styling in the literary and theatrical output of lateimperial China's literati have previously been explored in Huang (1995), and David Der-Wei Wang $(1997,2003)$.

18. We are again mindful here of Hans-Georg Gadamer's thoughts on the emergence of the "permanent" theatre in Germany in the late eighteenth century and the role of bourgeois society: "The structural transformation of social life that has taken place in this period is so profound and decisive that the social function of theatre was and still is bound to register this transformation" (1986: 57).

19. It may not be such a large leap as it appears. In the first pages of his Xianqing ouji (Sketches of Idle Pleasure) Li Yu goes very close to making the same comparison: "The composition of lyrics [for the theatre] is only a minor skill for men of letters, however if you have this ability it is much better than horseracing, swordplay, indulging in wine, or gambling” (Li 1992: 1). The analysis could also be enriched by reference to Bourdieu's (1990) notions of symbolic capital and symbolic violence, as well as Foucault's heterotopia (1986), approaches we intend to develop at a later date.

20. The boundaries between audience and stage were at least already porous through the composition of arias as a popular pastime.

21. There is much of what we have seen so far of the huapu in Barthes's own writings, including the theatricality of A Lover's Discourse: Fragments (1978) 
and the homoerotic wanderings in Tokyo hinted at in Empire of Signs (1982). See Scheie (2006).

22. Such layering of competitions is not unusual. The racetrack and competition between horses, jockeys, trainers, and owners comes to mind: these are played out in overlapping but not congruent forums: track, stud farm, bars, and banks. And then there are those who wager a bet.

23. In this regard our interpretation diverges from that of Andrea Goldman, who writes of huapu authors' "awareness of the stigma that was associated with the sex trade in boy actors" (2008: 5). We do not know of any evidence supporting the existence of such a stigma attached to literati men in nineteenth-century Beijing, nor, consequently, of huapu authors reflecting fear of such stigma in their writings. On the care required in interpreting attitudes to same-sex desire in late imperial China, see Stevenson and Wu (2005). For further discussion of male love see Wu and Stevenson (2006).

24. Other recent analyses focusing upon or using huapu also contribute to the need to recognize the epitheatrical dimension, see Joshua Goldstein (2007) and Andrea Goldman (2008). See also Tian Min (2000). Sophie Volpp's forthcoming Worldly Stage: Theatricality in Seventeenth-Century China also addresses the spread of theatrical modes of spectatorship into wider social spaces.

\section{GLOSSARY}

\author{
bangshou 榜首 \\ bangzi 梆子 \\ biji 筆記 \\ Bohua Jushi 播花居士 \\ boxue 博學 \\ caifeng 采風 \\ Cailou pei 彩樓配 \\ caizi jiaren 才子佳人 \\ Cemao yutan 側帽餘談 \\ Chen Hongshou 陳鴻壽 \\ Chen Sen 陳森 \\ Chen Weisong 陳維崧 \\ Cheng Changgeng 程長庚 \\ Chenyuan shilue 宸垣識略 \\ chuanqi 傳奇 \\ dan 旦 \\ de 德 \\ Dingnian yusun zhi丁年玉笛志 \\ Dong Jinbang 董金榜 \\ duocai duoyi 多才多藝 \\ Ershisi shi pin二十四詩品 \\ Fang Wenxi 方問溪
}

\author{
Fengcheng pinhua ji 鳳城品花記 \\ fengliu 風流 \\ Guangzhou's Master of Listening to \\ Spring Hall 羊城聽春樓主 \\ guwen shifu gexing 古文詩賦歌行 \\ Hongxi 鴻喜 \\ hua 花 \\ huabang 花榜 \\ hualian 花臉 \\ huapu 花譜 \\ huawang 花王 \\ jiayue 家樂 \\ jiguan 籍貫 \\ jingju 京劇 \\ Jinshen bianlan 絔紳便覽 \\ Jintai canleiji 金臺殘淚記 \\ Jiuqing tuyong 九青圖咏 \\ juan 卷 \\ juhua 菊話 \\ Ku'an shang $j u$ sh $i$ 苦庵賞菊詩 \\ kunqu 昆曲 \\ lao sheng 老生
}


Li Ciming 李慈銘

$\mathrm{Li} \mathrm{Yu}$ 李漁

liupai 流派

liyan 例言

liyuan 梨園

Lun Ming 倫明

Luo Pin 羅聘

Luoyuan 落園

Meihua meng 梅花夢

Menghua suobu 夢華瑣簿

Miaoshan 妙珊

Pan Guangdan 潘光旦

Paopo 跑坡

pihuang 皮黃

Pinghua xinpu 評花新譜

pinhua 品花

Pinhua baojian 品花寶鋻

pinti liyuan, cihuang renwu 品題梨

園䧳黃人物

$\mathrm{pu}$ 譜

pulu 譜錄

qing 情

Qingdai Yandu liyuan shiliao 清代燕都 梨園史料

Qinding libu zeli 欽定吏部則例

Qingtian waishi 情天外史

Qiuhu xiqi 秋胡戲妻

renwu 人物

Rixia jiuwen 日下舊聞

San jizhang 三擊掌

Sanniang jiaozi 三娘教子

seyi 色藝

Shenbaoguan 申報館

sheng 生

shenpin 神品

shidu 侍讀

shifu 師傅

Shuangzhaolou congshu隻隻樓叢書

Shuntianfu zhi 順天府志

shuobu 說部

Sikong Tu 司空圖

Siku quanshu zongmu 四庫全書總目

siyu 私寓

Suiyazhai 乿雅齋

Tan han yao 探寒窯
Tanqing yin 檀青引

Tiaoxiao ling 調笑令

Wan-Qing xiqu de biange 晚清戲曲的 變革

Wenge shuyi 聞歌述憶

wenrou 溫柔

wen-wu 文武

Wu Changyuan 吳長元

xianggong, 相公

Xiangxi Yuyin 香溪漁隱

Xianqing ouji 閒情偶寄

xiao ling 小伶

xiao sheng 小生

xiaoshuo 小說

Xinren guijia $l u$ 辛王癸甲錄

Xu Zhaoying 徐肇瑛

Xuannan zazu 宣南雜泠

Xuanwu gate 宣武門

xubian 續編

Yanjing zaji 燕京雜記

Yanlan xiaopu 燕蘭小譜

Yantai huashi 燕臺花史

Yantai jiyan ershisi huapin 燕臺集艷二 十四花品

Yantai jiyan 燕臺集豐

Yao Hua 姚華

Yao Shuyi 公書儀

Ye Dehui 葉德輝

Yi Shunding 易順鼎

Yilansheng 藝蘭生

yiyangqiang 七陽腔

Yuemangtang riji 越縵堂日記

Yuemantang juhua 越縵堂菊話

yun 韻

Yunlang chuyu tu 雲郎出浴圖

yunshi 韻事

Yuzhoufeng 宇宙鋒

zajia 雜家

Zhan Puguan 戰蒲關

Zhang Cixi 張次溪 (江裁)

zheng sheng 正生

Zhongxiangguo 眾香國

Zhu Yizun 朱彝尊

zhuangyuan 狀元

Ziyun 紫雲 


\section{REFERENCES}

Barthes, Roland. 1978 [1977].

A Lover's Discourse: Fragments. New York: Hill and Wang.

1982 [1970].

Empire of Signs, trans. by Richard Howard. New York: Hill and Wang.

2007 [1961].

What Is Sport? trans. by Richard Howard. New Haven, CT: Yale University Press.

Bourdieu, Pierre. 1990 [1979].

Distinction: A Social Critique of the Judgement of Taste, trans. by Richard Nice. Cambridge, MA: Harvard University Press.

Chen Sen. 1990 [1847].

Pinhua baojian (The Precious Mirror of Ranked Flowers). Shanghai: Shanghai guji chubanshe.

Clunas, Craig. 1991.

Superfluous Things: Material Culture and Social Status in Early Modern China. Cambridge: Polity Press.

Foucault, Michel. 1986.

"Of Other Spaces." Diacritics 16: 22-27.

Gadamer, Hans-Georg. 1986 [1954].

"The Festive Character of Theatre." The Relevance of the Beautiful and Other Essays, trans. by Nicholas Walker, 57-65. Cambridge: Cambridge University Press.

Goldman, Andrea. 2008.

"Actors and Aficionados in Qing Dynasty Texts of Theatrical Connoisseurship." Harvard Journal of Asiatic Studies 68 (1): 1-56.

Goldstein, Joshua. 2007.

Drama Kings: Players and Publics in the Re-Creation of Peking Opera, 1870 1937. Berkeley: University of California Press.

Harrison, George W. M. 2004.

"Plutarch the Dramaturg: Statecraft as Stagecraft in the Lives." In The Statesman in Plutarch's Works: Proceedings of the VI International Congress of the International Plutarch Society, edited by Lukas de Blois, Jeroen Bons, Ton Kessels, and Dirk M. Schenkeveldet, 53-60. Leiden: Brill.

Huang, Martin. 1995.

Literati and Self-re/presentation: Autobiographical Sensibility in the EighteenthCentury Chinese Novel. Stanford, CA: Stanford University Press.

Li Yu. 1992 [1671].

"Xianqing ouji juan yi, Shiqu bu shang, 'Jiegou'" (Sketches of Idle Pleasure, vol. 1, Poetry and Lyrics, "Structure"). In Liyu quanji di san juan (The Complete Works of Li Yu, vol. 3), 1-43. Hangzhou: Zhejiang guji chubanshe.

Louie, Kam. 2002.

Theorizing Chinese Masculinity: Society and Gender in China. Cambridge: Cambridge University Press. 
Mackerras, Colin. 1972.

The Rise of Peking Opera, 1780-1870: Social Aspects of the Theatre in Manchu China. Oxford: Clarendon Press.

McMahon, Keith. 2002.

"Sublime Love and the Ethics of Equality in a Homoerotic Novel of the Nineteenth Century." Nan Nü 4 (1): 70-109.

Scheie, Timothy. 2006.

Performance Degree Zero: Roland Barthes and Theatre. Toronto: University of Toronto Press.

Stevenson, Mark, and Wu Cuncun. 2005.

"Quilts and Quivers: Dis/covering Chinese Male Homoeroticism." Tamkang Review 15 (1): 119-167.

- trans. 2008.

"Notes on Flower Appreciation in the Phoenix City" (Xiangxi Yuyin). Renditions 69: 34-61.

Tian, Min. 2000.

"Male Dan: The Paradox of Sex, Acting, and Perception of Female Impersonation in Traditional Chinese Theatre." Asian Theatre Journal 17 (1): 78-97.

Vitiello, Giovanni. 1996.

"The Fantastic Journey of an Ugly Boy: Homosexuality and Salvation in Late Ming Pornography." Positions: East Asia Cultures Critique 4 (2): 291-320.

Volpp, Sophie. 2002.

"The Literary Circulation of Actors in Seventeenth-Century China." Journal of Asian Studies 61 (3): 949-986.

- Forthcoming.

The Worldly Stage: Theatricality in Seventeenth-Century China. Cambridge, MA: Harvard University Press.

Wang, David Der-wei. 1997.

Fin-de-siècle Splendor; Repressed Modernities of Late Qing Fiction, 1849-1911. Stanford, CA: Stanford University Press. 2003.

"Impersonating China." CLEAR 25: 133-163.

Wang Liqi. 1981.

Yuan-Ming-Qing sandai jinhui xiaoshuo xiqu shiliao (Historical Documents Relating to Prohibitions on Fiction and Drama in the Yuan, Ming and Qing Dynasties). Shanghai: Shanghai guji chubanshe.

Wu Cuncun. 2004.

Homoerotic Sensibilities in Late Imperial China. London: Routledge. 2006a.

"Imperial Chinese Theater." In Encyclopaedia of Prostitution and Sex Work, edited by Melissa Hope Ditmore, 220-222. New York: Greenwood Publishing Group.

2006b.

“'Ruanhong chenli zhu xinshu': Xiangxi Yuyin Fengcheng pinhua ji yu 
wan-Qing de huapu," (New Books Composed amid the Dust of Red Carpets: Xiangxi Yuyin's Notes of Flower Appreciation from the Phoenix City and the Late-Qing "Flower Guides"). Zhongguo Wenhua (Chinese Culture) 23: 73-85.

Wu Cuncun and Mark Stevenson. 2006.

"Male Love Lost: The Fate of Male Same-Sex Prostitution in Beijing in the Late Nineteenth and Early Twentieth Centuries." In Embodied Modernities: Corporeality, Representation, and Chinese Cultures, edited by Fran Martin and Larissa Heinrich, 42-59. Honolulu: University of Hawai'i Press.

Yao Shuyi. 2006.

Wan-Qing xiqu de biange (The Transformation of Late Qing Theatre). Beijing: Renmin wenxue.

Zhang Cixi, ed. 1988 [1934, 1937].

Qingdai Yandu liyuan shiliao (including xubian) (Historical Materials on Opera Circles of the Capital in the Qing Dynasty, Including Supplement), Beijing: Zhongguo xiju chubanshe. 